Акімова Л. М., д.н.держ.упр., професор кафедри фінансів та економіки природокористування,

Любовська М. М., здобувач вищої освіти другого (магістерського) рівня

(Національний університет водного господарства та природокористування, м. Рівне)

\title{
БАНКИ 3 ДЕРЖАВНОЮ УЧАСТЮ: ОЦІНКА РИЗИКІВ ВИСОКОЇ ЧАСТКИ ÏХ КАПІТАЛУ В БАНКІВСЬКОМУ СЕКТОРІ ТА ШЛЯХИ ЇХ МІНІМІЗАЦІї
}

Статтю присвячено аналізу основних показників розвитку банків із державною участю в Україні. Здійснено аналіз обсягів докапіталізації, зобов'язань та власного капіталу банків з державною участю. Проведено порівняння фінансового результату діяльності вітчизняних банків 3 державною участю. Визначено ключові проблеми державних банків у сучасних умовах та запропоновано напрями підвищення фінансової стабільності банків з державною участю.

Ключові слова: банк; банк із державною участю; банківська система; управління банками 3 державною участю; фінансова стабільність; фінансовий результат діяльності банку.

Постановка проблеми. У Європі державні банки рідко $€$ ключовими учасниками фінансового сектору. В Україні ж вони відіграють системну роль. Висока частка державного капіталу в українському банківському секторі - наслідок криз. Нині держбанки, насамперед Ощадбанк та Укрексімбанк, мають ряд фундаментальних проблем, зокрема незадовільну якість активів, низьку процентну маржу та операційну ефективність. Унаслідок цього вони неспроможні самостійно генерувати капітал. Оскільки ці банки $\epsilon$ великими гравцями, виникають системні ризики для всього сектору. Тому дослідження діяльності банків із державною участю, сучасних проблем їх функціонування та можливостей щодо забезпечення фінансової стабільності банківського сектору України в сучасних умовах набуває особливої актуальності.

Аналіз останніх досліджень i публікацій. Значну увагу питанням функціонування і розвитку банків із державною участю приділено у наукових працях таких учених, як О.Д.Вовчак, О.С. Деревко, Т.Г.Дзюба, М.І.Крупка, Л. К. Кульпінська, В. В. Оніщенко, Л. О. Примостка, К. В. Рожкова та інші. Незважаючи на вагомий внесок науковців у дослідження зазначеного питання, зміни, що відбулися у структурі власності банківської системи 
України, потребують актуалізації аналізу показників розвитку банків із державною участю.

Постановка завдання. Метою даної роботи $\epsilon$ дослідження діяльності держаних банків, причин домінуючої державної частки власності в банківській системі України, переваг та недоліків функціонування банків 3 державною участю, а також перспектив розвитку в умовах необхідності забезпечення фінансової стабільності банківського сектору.

Виклад основного матеріалу. Банки з державною участю мають важливе значення у соціально-економічному розвитку держави. Ці банки є своєрідною запорукою збереження істотної частки вітчизняного капіталу в банківській системі. Існують різні підходи до трактування поняття «державний банк» та «банк 3 державною часткою». На думку В. В. Оніщенко, «державний банк» це банківська установа, метою діяльності якої $\epsilon$ не отримання прибутку, а виконання функцій фінансових агентів уряду при реалізації програм соціально-економічного розвитку, в якому $100 \%$ статутного капіталу належить органам державної влади, який в управлінні підпорядкований цим органам, рівень контролю держави над яким визначається відповідними нормативними актами. Водночас, поняття «банк з державною участю», на думку автора, $\epsilon$ більш загальним і включає банки: над активами яких органи державної влади або державні підприємства здійснюють прямий чи опосередкований контроль; в капітал яких держава входить прямо чи опосередковано на постійній чи тимчасовій основі в різних частинах та, відповідно, з різною метою [8]. Досліджуючи позицію Т.Г.Дзюби щодо трактування поняття «державний банк», можна стверджувати, що він відносив до даної категорії будь-який банк, що контролюється державою, не враховуючи розмір державної частки в статутному капіталі. Тобто, можна стверджувати, що він ототожнює поняття «державний банк» 3 поняттям «банк, з державною участю» [3].

Згідно з Законом України «Про банки та банківську діяльність» державний банк - це банк, $100 \%$ статутного капіталу якого належать державі. Державний банк створюється за рішенням Кабінету Міністрів України [4]. Згідно з даним законодавчим підходом до поняття «державні банки», ті банки, які мають частку державної власності менше показника $100 \%$ не можливо назвати державними банками. Проте, станом на 01.09.2019 в структурі всіх банків 3 державною участю відсоток власності державних органів в структурі статутних капіталів знаходиться понад 75\%, що надає їй безумовні права на управління даним банком. Таким чином, ця ситуація в сучасних умовах нівелює різницю між поняттями «державний банк» 
та «банк з державною часткою».

На думку Л.К.Кульпінської [7] перед банками з державною участю стоїть дві групи задач. Першу групу можна віднести до комерційних задач, коли пріоритети надаються отриманню та максимізації прибутку, підвищення вартості банку, збільшенню частки ринку. Друга група задач пов'язана з особливим соціальним статусом банків з державною участю в економіці.

Розглядаючи задачі другої групи науковцем виділено основні цільові функції банків з державною участю:

- фінансова підтримка пріоритетних задач держави та структурних реформ;

- стимулювання розвитку фінансових ринків;

- подолання криз та пом'якшення їх наслідків.

На нашу думку, з метою більш повного обґрунтування змісту діяльності банків 3 державною участю, яка полягає у сприянні соціально-економічному зростанню в країні, необхідним $\epsilon$ доповнення виділених вченими функцій таким чином:

- сприяння розвитку інноваційної економіки через зниження вартості джерел фінансування для пріоритетних галузей економіки;

- компенсація недоліків ще не достатньо сформованого ринкового механізму;

- забезпечення економічної безпеки держави, зменшуючи вплив іноземного капіталу в банківській системі;

- активізація розвитку малого і середнього бізнесу, що обумовлено організацією взаємовигідного фінансового партнерства та наданням кредитних ресурсів на пільгових умовах.

Проаналізуємо зміни у загальній чисельності банків та банків 3 державною участю (табл. 1), а також частки активів банків 3 державною участю у загальному обсязі активів банківської системи за 2015-2019 рр. (рис. 1).

Таблиця 1

Динаміка кількості банків в Україні та банків 3

державною участю за 2015-2019 рр.

\begin{tabular}{|l|c|c|c|c|c|}
\hline \multicolumn{1}{|c|}{ Банки } & 2015 р. & 2016 p. & 2017 p. & 2018 p. & 01.09 .2019 p. \\
\hline Платоспроможні & 117 & 96 & 82 & 77 & 76 \\
\hline Державні & 7 & 6 & 5 & 5 & 5 \\
\hline Іноземні & 25 & 25 & 23 & 21 & 21 \\
\hline Приватні & 85 & 65 & 54 & 51 & 50 \\
\hline Неплатоспроможні & 3 & 4 & 2 & 1 & 0 \\
\hline
\end{tabular}

Джерело: складено на основі [9]

3 табл. 1 ми бачимо, що упродовж 2015-2019 рр. відбувалося 
поступове зменшення кількості діючих банків у банківській системі України (зі 117 за підсумками 2015 року до 76 на 01.09.2019р.). Кінець 2016 року відзначився входженням до структури державних банків ПАТКБ «Приватбанк». У 2015-2019 рр. спостерігаємо зниження державної власності на банки в Україні (з 7 до 5 банків відповідно), однак, як бачимо з рис. 1, саме у цей період значно зросла частка активів банків з державною участю у загальному обсязі активів банківської системи (з 49,2\% за підсумками 2015 року до 54,2\% за підсумками 2019 року).

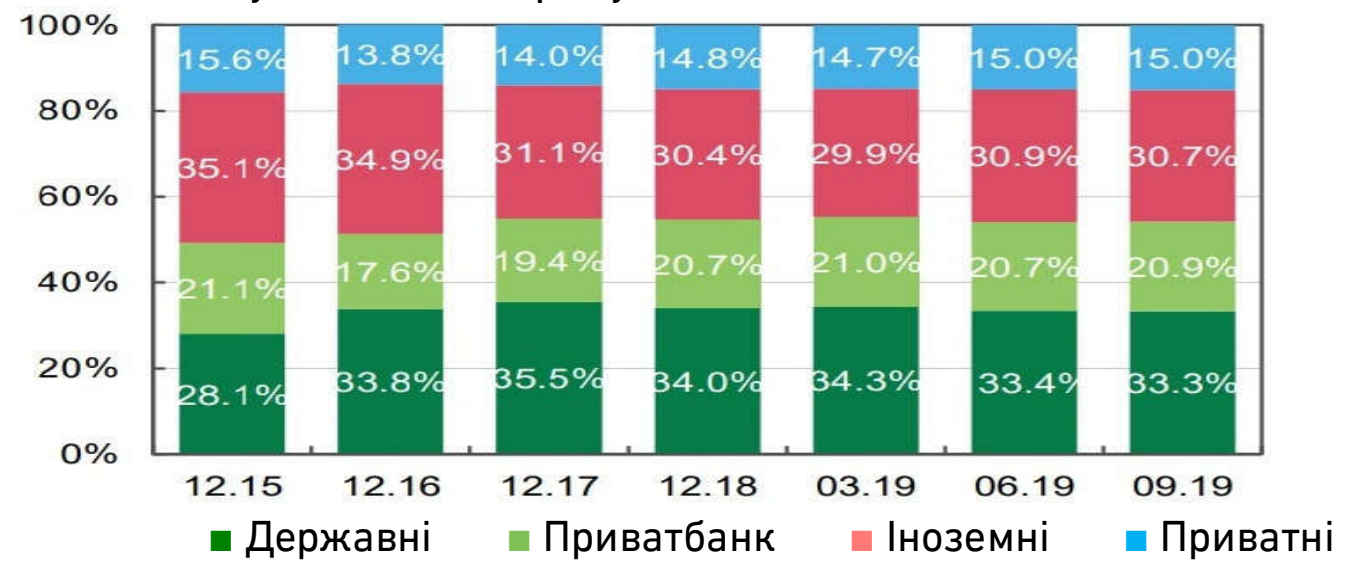

Рис. 1. Розподіл чистих активів за групами банків за 2015-2019 рр. Джерело: [9]

Однією з основних причин зміни структури власності активів вітчизняної банківської системи виступає саме докапіталізація банків із державною участю (рис. 2).

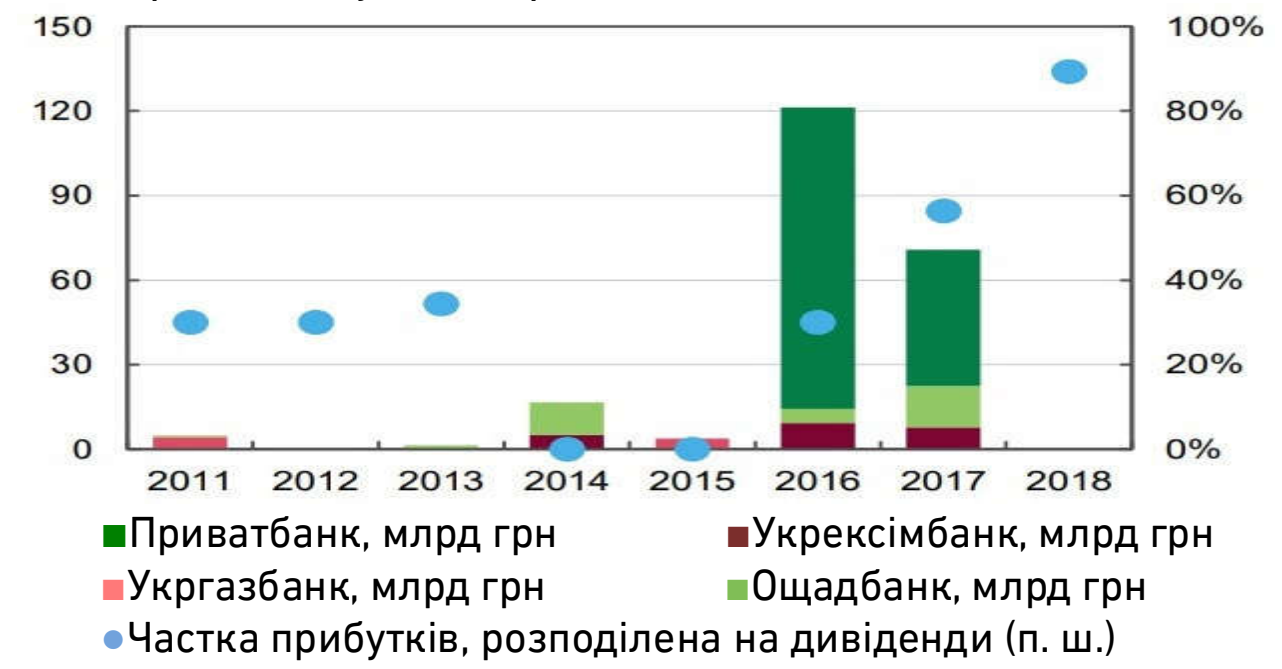

Рис. 2. Витрати на докапіталізацію державних банків та частка їх прибутків, розподілена на дивіденди за 2011-2018 pр.

Джерело: [5] 
3 рис. 2 видно, що упродовж досліджуваного періоду з 2011 до 2018 року банки з державною участю активно докапіталізовувалися. Ці заходи здійснювалися як за рахунок державного бюджету, так і за рахунок прибутків банків, але здебільшого капіталізація банків 3 державною участю реалізовувалася шляхом випуску облігацій внутрішньої державної позики. «Приватбанк» став державним в грудні 2016-го року внаслідок націоналізації, для його докапіталізації уряд випустив облігації внутрішньої держпозики на 116,8 млрд грн.

Так, науковець О. С. Деревко у своїй праці зазначає про «відсутність належного планування заходів із підтримки державних банків за рахунок випуску облігацій внутрішньої державної позики. Заходи зазвичай розглядалися під час складання проєкту закону про державний бюджет на відповідний бюджетний період. Проєкти законів про державний бюджет в частині його фінансування не містили відповідних розрахунків та обґрунтувань, що не відповідає чинному бюджетному законодавству. Вартість державних запозичень, визначена у відповідних постановах уряду, значно відрізнялася від вартості боргових інструментів, які можна було отримати у той час на фінансовому ринку України» [2].

Погоджуємося 3 позицією вченого, що докапіталізація банків шляхом випуску облігацій внутрішньої державної позики та обміну їх на акції нової емісії має негативні наслідки для економіки України, «залучення коштів на фінансовому ринку України за таким підходом негативно впливає на фінансову та бюджетну систему, погіршує конкуренцію, підвищує дефіцит вільних коштів на фінансовому ринку, скорочує обсяги кредитування реального сектору економіки, що може провокувати поглиблення економічних кризових явищ» [2].

Для більш повної характеристики сучасного стану вітчизняних банків з державною участю проаналізуємо структуру їхніх ресурсів (табл. 2).

Таблиця 2

Динаміка зобов'язань та власного капіталу банків з державною участю в Україні у 2017-2019 рр. (млн грн)

\begin{tabular}{|l|c|c|c|c|c|c|}
\hline \multirow{2}{*}{ Банк } & \multicolumn{3}{|c|}{ Зобов'язання } & \multicolumn{3}{c|}{ Власий капітал } \\
\cline { 2 - 8 } & 31.12. & 31.12. & 01.09. & 31.12. & 31.12. & 01.09. \\
& 2017 & 2018 & 2019 & 2017 & 2018 & 2019 \\
\hline Укрексімбанк & 156554 & 153184 & 133238 & 14063 & 8441 & 9977 \\
\hline Ощадбанк & 202590 & 199209 & 189488 & 31251 & 18542 & 18619 \\
\hline Приватбанк & 230012 & 246545 & 237059 & 24793 & 31575 & 47327 \\
\hline Укргазбанк & 63587 & 76468 & 97958 & 5625 & 5756 & 6418 \\
\hline
\end{tabular}




\begin{tabular}{|c|c|c|c|c|c|c|}
\hline \begin{tabular}{|l} 
Усього по банках \\
3 \\
участю (млн грн)
\end{tabular} & 652743 & 675406 & 657743 & 75732 & 64314 & 82341 \\
\hline \begin{tabular}{|ll} 
Частка & по \\
відношенню & до \\
банківської & \\
системи (\%) &
\end{tabular} & 55,66 & 56,06 & 54,86 & 47,01 & 41,51 & 45,48 \\
\hline
\end{tabular}

Джерело : складено на основі [10]

За даними табл. 2 можемо проаналізувати динаміку зобов'язань чотирьох банків з державною участю за 2017-2019 рр. Зазначимо, що у всіх банків упродовж досліджуваного періоду відбувалося зменшення обсягів зобов'язань, окрім «Укргазбанку». Так, за 3 роки зобов'язання «Укрексімбанку» зменшились на 14,9\%, Ощадбанку на 6,5\%, Приватбанку на 3,8\%, а «Укргазбанку» навпаки зросли на 54,1\%. Зменшення зобов'язань цих банків та їх частки у загальному обсязі зобов'язань банківської системи $(54,86 \%$ станом на 01.09.2019 р.) свідчить про незначне звуження депозитної бази даних банків.

Крім того, за аналізований період значення власного капіталу як одного 3 найважливіших показників надійності банківської установи «Приватбанку» та «Укргазбанку» поступово зростає, «Ощадбанку» та «Укрексімбанку» навпаки зменшується. Тенденції зростання власного капіталу можна пов'язати з підвищенням вимог Національного банку України до статутного капіталу та зі значними обсягами докапіталізації цих банків.

Загалом за 2017-2019 рр. власний капітал банків з державною участю зріс на $8,7 \%$. Щодо частки державного капіталу у сукупному власному капіталі банківської системи, то у 2018 р. можна прослідкувати зменшення на 5,5\%, проте вже у 2019 р. рівень державного капіталу становив $45,48 \%$ по відношенню до банківської системи, що на 3,97\% вище порівняно з 2018 р.

Щодо фінансового результату діяльності банків з державною участю, то упродовж 2017-2019 рр. ми спостерігаємо неоднозначну його динаміку (рис. 3). Станом на 01.09.2019 р., ми бачимо, тенденцію до стрімке зростання фінансових результатів у «Укрексімбанку» та поступове у «Приватбанку», у 2019 р. прибуток «Приватбанку» становив 27522 млн грн, попри колосальний збиток у 2017 році 22,8 млрд грн, прибуток «Укрексімбанку» за 3 роки зріс на $189,5 \%$. Фінансові результати інших двох банків з державною часткою, таких 
як «Укргазбанк» та «Ощадбанк», суттєво знижуються відповідно на $44,7 \%$ та $66,1 \%$ у 2019 р. порівняно з 2017 р.

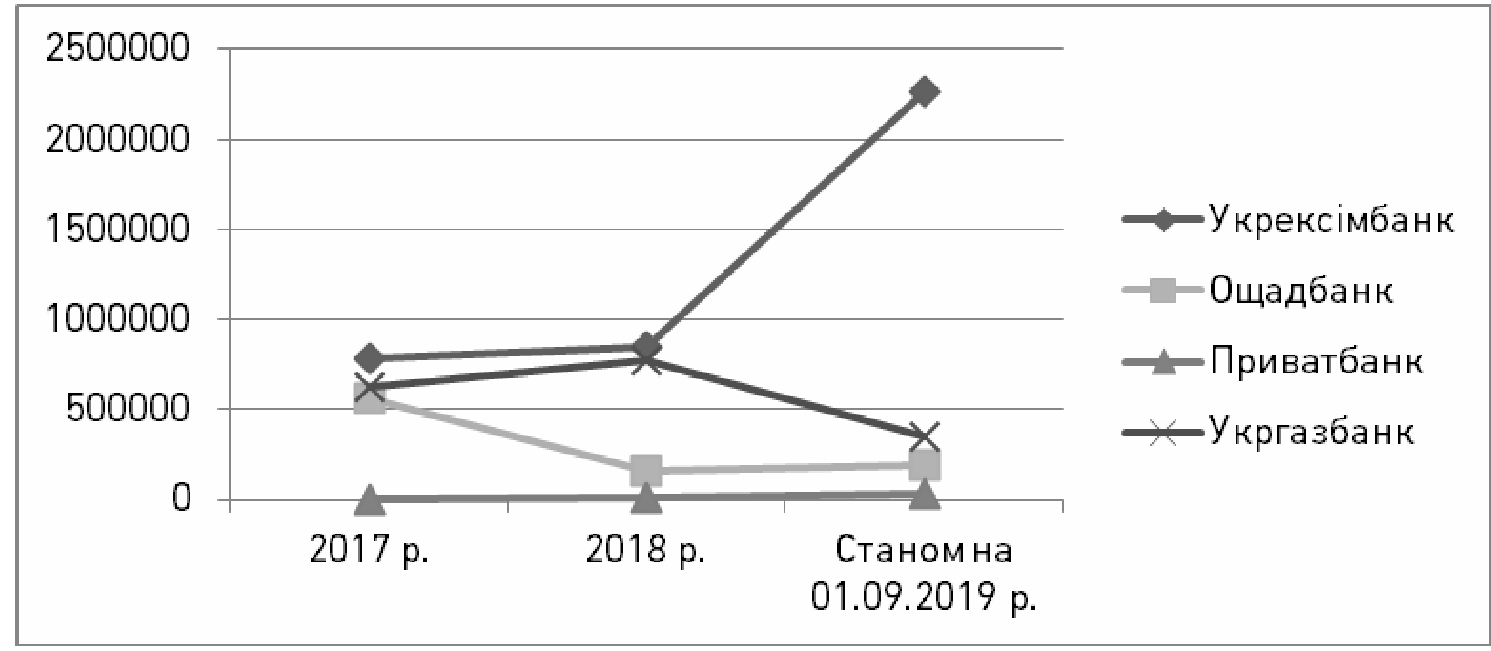

Рис. 3. Фінансовий результат діяльності банків з державною участю за 2017-2019 рр. (млн грн)

Джерело : складено на основі [10]

Отже, проаналізувавши основні показники діяльності банків 3 державною участю в Україні, ми дійшли висновку про наявний значний потенціал їхнього розвитку, але, водночас і неефективність діяльності на сучасному етапі, що зумовлено такими факторами:

- політизованість банків з державною участю, тобто діяльність цих банків має великий ризик бути спрямованою на підтримку інтересів політичної еліти країни;

- орієнтація більшості банків з державною участю на фінансову підтримку неефективних з комерційного погляду галузей економіки та проєктів, які мають важливе значення для держави, але можуть бути і неефективними з комерційного погляду. 3 огляду на великий розмір збитків, банки з державною участю можуть становити загрозу для платоспроможності держави і ставати джерелом інфляційного фінансування дефіциту [6];

- менш ефективне корпоративне управління у банках 3 державною участю порівняно 3 приватними банківськими установами. Менеджмент державних банків, як правило, має відносно менше стимулів до скорочення витрат та максимізації прибутку банку [1].

У підсумку за кілька років держава має суттєво знизити свою участь у капіталі банків, для цього НБУ зазначає основні напрями:

- підпорядкувати роботу банків одній ключовій меті максимізації вартості банку для власника, тобто держави. Фокус має 
бути на збільшенні прибутковості та віддачі капіталу, а не на збереженні чи збільшенні частки ринку;

- здійснити швидке розчищення балансів від непрацюючих кредитів, більшість з яких належно зарезервовані;

- визначити пріоритетні напрями кредитування, що підвищать процентну маржу;

- посилити кредитну аналітику та експертизу. Впровадити належні системи ризик-менеджменту;

- оптимізувати операційні витрати. Переоцінити бюджети 3 огляду на віддачу від здійснених та запланованих інвестиційних проєктів [5].

Висновки. У кризових та посткризових умовах держава приділяє значну увагу державним банкам, створюючи основу для фінансової стабілізації банківської системи. Внаслідок націоналізації ПАТ «Приватбанк» частка державних банків в структурі активів та зобов'язань банківської системи України значно зросла, саме банки 3 державною участю займають домінуючу позицію на ринку банківських послуг. Проте, у сучасних умовах реформування банківської системи України, політичної та економічної нестабільності в державі, банки за участі державного капіталу мають ряд проблем, що можливо подолати за допомогою впровадження адміністративно-правових та економічних заходів макроекономічного та мікроекономічного характеру. За умов підвищення фінансової стабільності, банки за участю державного капіталу мають достатній ресурсний, стратегічний та адміністративний потенціал для стабілізації ситуації в банківському секторі. Поряд з цим, поглибленого дослідження потребують напрями підвищення конкурентних позицій банків 3 державною часткою, особливо в умовах системних макроекономічних дисбалансів, але не зловживаючи можливістю їх докапіталізації коштом платників податків.

1. Вовчак О. Д. Особливості посткризового розвитку державних банків в Україні. Вісник Університету банківської справи Національного банку України. 2013. № 2 (17). С. 135-138. 2. Деревко О. С. Капіталізація державних банків як боргоутворюючий чинник в Україні : автореф. дис. .... канд. екон. наук : 08.00.08. Київ, 2017. 21 с. 3. Дзюба Т. Г. Шляхи підвищення капіталізації банківських установ за участю держави в умовах фінансової нестабільності. Наукові записки Національного університету «Острозька академія». 2009. Вип. 12. С. 196-204. URL: http://nbuv.gov.ua/UJRN/Nznuoa_2009_12_26 (дата звернення: 20.02.2020). 4. Про банки і банківську діяльність (зі змінами та доповненнями) : Закон України. Відомості Верховної Ради України. 2001. № 56. URL: http://zakon5.rada.gov.ua/laws/show/2121-14. (дата звернення: 20.02.2020). 5. Звіт про фінансову стабільність НБУ, грудень 2019 року : вебсайт. URL: https://bank.gov.ua/admin_uploads/article/FSR_2019-H2.pdf?v=4 (дата звернення: 
20.02.2020). 6. Крупка М.І. Фінансові інновації державних банків України. Фінансовий простір. № 4 (16), 2014. С. 127-131. 7. Кульпінська Л. К. Стимулювання інвестиційного розвитку через трансформацію діяльності державних банків. Бізнес-інформ. 2013. № 12. С. 297-301. 8. Оніщенко В. В. Аналіз діяльності державних банків в Україні. Вісник СумДУ. Сер. Економіка. 2012. № 2. С. 186-192. 9. Огляд банківського сектору НБУ, листопад 2019 р. : вебсайт. URL: https://bank.gov.ua/ admin_uploads/article/ Banking_Sector_Review_201911.pdf?v=4 (дата звернення: 20.02.2020). 10. Показники банківської системи України : вебсайт. URL: https://bank.gov.ua/control/uk/publish/ (дата звернення: 20.02.2020).

\section{REFERENCES:}

1. Vovchak O. D. Osoblyvosti postkryzovoho rozvytku derzhavnykh bankiv v Ukraini. Visnyk Universytetu bankivskoi spravy Natsionalnoho banku Ukrainy. 2013. № 2 (17). S. 135-138. 2. Derevko 0. S. Kapitalizatsiia derzhavnykh bankiv yak borhoutvoriuiuchyi chynnyk v Ukraini : avtoref. dys. .... kand. ekon. Nauk : 08.00.08. Kyiv, 2017. 21 s. 3. Dziuba T. H. Shliakhy pidvyshchennia kapitalizatsii bankivskykh ustanov za uchastiu derzhavy $v$ umovakh finansovoi nestabilnosti. Naukovi zapysky Natsionalnoho universytetu «Ostrozka akademiia». 2009. Vyp. 12. S. 196-204. URL: http://nbuv.gov.ua/UJRN/Nznuoa_2009_12_26 (data zvernennia: 20.02.2020). 4. Pro banky i bankivsku diialnist (zi zminamy ta dopovnenniamy) : Zakon Ukrainy. Vidomosti Verkhovnoi Rady Ukrainy. 2001. № 56. URL: http://zakon5.rada.gov.ua/laws/show/2121-14 (data zvernennia: 20.02.2020). 5. Zvit pro finansovu stabilnist NBU, hruden 2019 roku: veb-sait. URL: https://bank.gov.ua/admin_uploads/article/FSR_2019-H2.pdf?v=4 (data zvernennia: 20.02.2020). 6. Krupka M. I. Finansovi innovatsii derzhavnykh bankiv Ukrainy. Finansovyi prostir. № 4 (16), 2014. S. 127-131. 7. Kulpinska L. K. Stymuliuvannia investytsiinoho rozvytku cherez transformatsiiu diialnosti derzhavnykh bankiv. Biznes-inform. 2013. № 12. S. 297-301. 8. Onishchenko V. V. Analiz diialnosti derzhavnykh bankiv v Ukraini. Visnyk SumDU. Ser. Ekonomika. 2012. № 2. S. 186-192. 9. Ohliad bankivskoho sektoru NBU, lystopad 2019 r. : veb-sait. URL: https://bank.gov.ua/ admin_uploads/article/ Banking_Sector_Review_201911.pdf? $v=4$ (data zvernennia: 20.02.2020). 10. Pokaznyky bankivskoi systemy Ukrainy : veb-sait. URL: https://bank.gov.ua/control/uk/publish/ (data zvernennia: 20.02.2020).

Akimova L. M., Doctor of Science in Public Administration, Professor of the Department of Finance and Economics of Environmental

Management,

Liubovska M. M., Senior Student

(National University of Water and Environmental Engineering, Rivne)

\section{STATE-OWNED BANKS: RISK ASSESSMENT OF THE HIGH SHARE OF THEIR CAPITAL IN THE BANKING SECTOR AND THE WAYS OF MINIMIZING THEM}

In Europe, state-owned banks are not always key players in the financial sector. In Ukraine, they play systemic role. A high share of state 
capital in the Ukrainian banking sector is a consequence of crises. Today, state-owned banks, notably Oschadbank and Ukreximbank, have a number of fundamental problems, including unsatisfactory asset quality, low interest margins and operational efficiency.

The article is devoted to the analysis of the basic indicators of stateowned banks development in Ukraine. Approaches to the interpretation of the concept of a «state-owned bank» are determined. Changes in the total number of banks and state-owned banks are analyzed, as well as the assets of state-owned banks in the total volume of assets of the banking system for 2015-2019. The volume of capitalization of Oshchadbank, Ukreximbank, PrivatBank, and Ukrgasbank has been analyzed. The dynamics of obligations and the own capital of state-owned banks have been considered. The results of the financial activities of domestic state-owned banks are compared. The key problems of state-owned banks in modern conditions are identified. There are the directions proposed for improving the financial stability of state-owned banks, namely:

- to subordinate the work of the bank to one key goal - to maximize the value of the bank for the owner, i.e. the state. There should be focus on increasing profitability and return on capital rather than on maintaining an increasing market share;

- to quickly clear the balance of non-performing loans, most of which are properly reserved;

- to identify priority lending directions that will increase the interest margin;

- to strengthen credit analytics and expertise; implement appropriate risk management systems;

- optimize operating costs; re-evaluate budgets in terms of the return on implemented and planned investment projects.

Keywords: bank; state-owned banks; banking system; state-owned banks management; financial stability; bank financial results.

Акимова Л. Н., д.н.гос.упр., профессор кафедры финансов та экономики природопользования,

Любовская М. М., соискатель высшего образования второго (магистерского) уровня (Национальный университет водного хозяйства и природопользования, г. Ровно)

\section{БАНКИ С ГОСУДАРСТВЕННЫМ УЧАСТИЕМ: ОЦЕНКА РИСКОВ ВЫСОКОЙ ДОЛИ ИХ КАПИТАЛА В БАНКОВСКОМ СЕКТОРЕ И ПУТИ ИХ МИНИМИЗАЦИИ}

\footnotetext{
Статья посвящена анализу основных показателей развития банков с государственным участием в Украине. Определены подходы к 12
} 
трактовке понятия «банк с государственным участием». Проанализированы изменения в общей численности банков и банков с государственным участием, а также доли активов банков с государственным участием в общем объеме активов банковской системы за 2015-2019 гг. Проведен анализ объемов докапитализации «Ощадбанка», «Укрэксимбанка», «Приватбанка», «Укргазбанка». Рассмотрена динамика обязательств и собственного капитала банков с государственным участием. Проведено сравнение финансового результата деятельности отечественных банков с государственным участием. Определены ключевые проблемы государственных банков в современных условиях. Предложенные направления повышения финансовой стабильности банков с государственной долей.

Ключевые слова: банк; банк с государственным участием; банковская система; управление банками с государственным участием; финансовая стабильность; финансовый результат деятельности банка. 